\title{
Gaseous elemental and reactive mercury in Southern New Hampshire
}

\author{
J. M. Sigler, H. Mao, and R. Talbot \\ Institute for the Study of Earth, Oceans and Space, Climate Change Research Center, University of New Hampshire, Durham, \\ New Hampshire 03824, UK
}

Received: 7 August 2008 - Published in Atmos. Chem. Phys. Discuss.: 30 September 2008

Revised: 10 February 2009 - Accepted: 10 March 2009 - Published: 19 March 2009

\begin{abstract}
We conducted measurements of $\mathrm{Hg}^{0}$ and RGM at two inland sites, Thompson Farm (TF) and Pac Monadnock (PM), and a marine site (Appledore Island (AI)) from the UNH AIRMAP observing network in New Hampshire in 2007. Measurements of other important trace gases and meteorological variables were used to help understand influences on the atmospheric Hg budget in New England. Seasonal variation in both species observed at TF and PM is attributable to such factors as seasonal variation in deposition strength, meteorological conditions and biogenic emissions. $\mathrm{Hg}^{0}$ and RGM varied diurnally at $\mathrm{TF}$, particularly in spring, following the trend in air temperature and $j \mathrm{NO}_{2}$ and suggesting photochemical production of RGM. The diurnal patterns of $\mathrm{Hg}^{0}$ and RGM at AI during summer were nearly opposite in phase, with $\mathrm{Hg}^{0}$ decreasing through late afternoon, suggesting more significant photochemical oxidation of $\mathrm{Hg}^{0}$ to $\mathrm{RGM}$ in the marine environment, likely due to the presence of marine halogen compounds. A significant relationship of RGM with $\mathrm{SO}_{2}$ at TF suggests a strong contribution of RGM from anthropogenic sources. Significant levels of halogen compounds measured at TF in previous studies, as well as similar $\mathrm{Hg}^{0}$ levels and $\mathrm{Hg}^{0}-\mathrm{CO}$ ratios at TF and AI may suggest that similar air masses are prevalent at these sites.
\end{abstract}

\section{Introduction}

Mercury ( $\mathrm{Hg}$ ) has been identified as a potentially hazardous contaminant. $\mathrm{Hg}$ is emitted to the atmosphere primarily by combustion sources, and the regional public health impact may be dependent on the chemical form of the emitted species (EPA, 1997). Total gaseous mercury (TGM) in

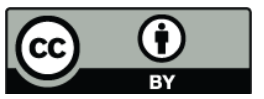

Correspondence to: J. M. Sigler

(jsigler@gust.sr.unh.edu) the atmosphere consists of two primary forms, elemental $\mathrm{Hg}$ $\left(\mathrm{Hg}^{0}\right)$ and divalent reactive gaseous $\mathrm{Hg}$ (RGM). Hg reportedly comprises $>95 \%$ of the global atmospheric pool of $\mathrm{Hg}$, is thought to have a lifetime of several months to a year and can therefore be transported over long distances before deposition. RGM typically represents $<5 \%$ of atmospheric $\mathrm{Hg}$ and has an atmospheric lifetime on the order of hours to days.

A primary source of RGM is combustion, which comprises at least $50 \%$ and $60 \%$ of total $\mathrm{Hg}$ emissions from coal-fired power plants (Carpi, 1997) and municipal waste combustors respectively. RGM undergoes dry/wet deposition much faster than $\mathrm{Hg}^{0}$ because of its high solubility and thus deposits close $(<100 \mathrm{~km})$ to its emission source (Lindberg and Stratton, 1998). Ecosystems located near emission sources may receive significant inputs of reactive $\mathrm{Hg}$, which can enter the food chain and pose a threat to ecosystem and public health (EPA, 1997). This is of particular concern in the Northeastern United States, where high Hg emissions result from a large number of power plants and municipal waste combustors serving large populations (EPA, 1997; NESCAUM, 2005), and a number of biogenic Hg "hot spots" and other areas of concern have been identified in New York and throughout New England (Evers et al., 2007).

RGM can also be produced by local oxidation of $\mathrm{Hg}^{0}$ (Weiss-Penzias, 2003; Poissant et al., 2004). As a result, RGM levels are highly variable due to changes in local pollution sources and meteorology. Accurate quantification of $\mathrm{Hg}^{0}$ and RGM at fine time resolution and over long sampling periods ( $\geq 1$ year) is therefore critical toward elucidating anthropogenic, chemical and meteorological influences on regional $\mathrm{Hg}$ budgets. This will help improve $\mathrm{Hg}$ modeling schemes and evaluate/develop regulatory strategies.

Relatively few field campaigns have conducted speciated $\mathrm{Hg}$ measurements. A majority of a limited number of studies in North America have been short-term intensive campaigns over periods of several weeks to months (e.g., Malcolm et

Published by Copernicus Publications on behalf of the European Geosciences Union. 


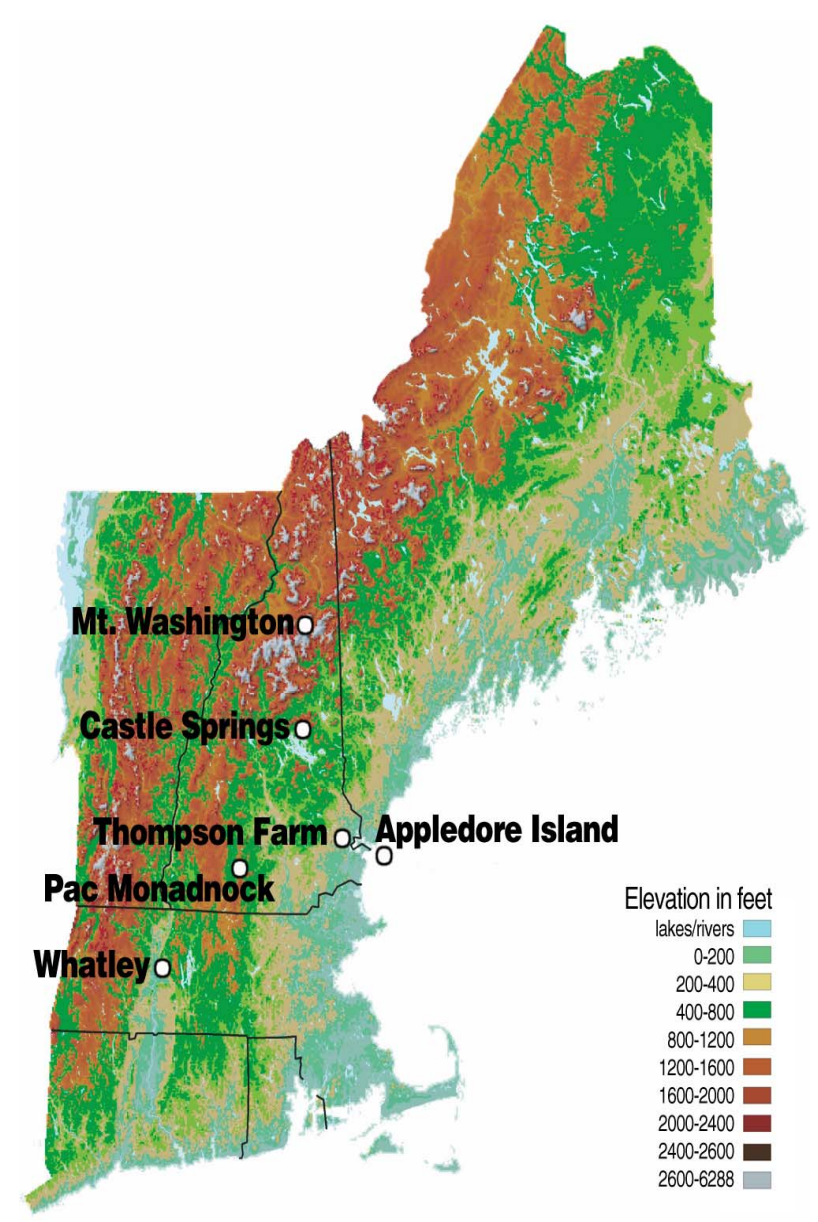

Fig. 1. AIRMAP monitoring network ( $\mathrm{Hg}$ is measured at Thompson Farm, Pac Monadnock and Appledore Island).

al., 2003; Gabriel et al., 2005). Three recent studies undertook year-round measurements of $\mathrm{Hg}^{0}$, RGM and particulate $\mathrm{Hg}$ in Quebec, Canada (Poissant et al., 2005), the Ohio River Valley (Yatavelli et al., 2006), and in urban and rural sites in Michigan (Liu et al., 2007). These studies revealed imprints of both local and regional sources on atmospheric $\mathrm{Hg}$ and showed clear diurnal and seasonal variation in $\mathrm{Hg}^{0}$ and RGM. The results underscore the importance of longterm, high-resolution measurements of these species, especially in areas influenced by pollution from urban/industrial sectors. The AIRMAP program at the University of New Hampshire (UNH) conducts year-round, continuous air quality measurements at a network of sites in rural New England, USA. These sites are downwind of major urban and industrial pollution sources in the US northeastern corridor. Mao et al. (2008), using multiple years of continuous AIRMAP measurements of $\mathrm{Hg}$ together with a suite of trace gases, showed distinct diurnal variability and seasonality in $\mathrm{Hg}^{0}$ mixing ratios and quantified the regional background level of $\mathrm{Hg}^{0}$ as well as the anthropogenic influence in Northern New
England. Their results also suggested a strong depositional sink for $\mathrm{Hg}^{0}$ and the possible influence of halogen chemistry on $\mathrm{Hg}^{0}$ mixing ratios near the coast. However, the study did not include RGM measurements, which are crucial toward a full understanding of physical and chemical processes influencing the regional atmospheric mercury cycling in New England.

In this study, we discuss measurements of $\mathrm{Hg}^{0}$ and RGM at three AIRMAP sites during 2006-2007. This study builds upon the work of Mao et al. (2008) and represents one of very few continuous, multi-site $\mathrm{Hg}^{0} / \mathrm{RGM}$ measurement campaigns in the US. The dramatic differences among measurement sites in terms of surface characteristics, elevation, and proximity to urban and marine environments provides a unique opportunity to examine the impact of local and regional-scale anthropogenic as well as natural and marine processes on atmospheric $\mathrm{Hg}$. We describe and interpret observed trends in $\mathrm{Hg}^{0}$ and RGM on diurnal and seasonal time scales, examine relationships of RGM with other pollutants as well as meteorological variables, and give consideration to geographical variation of $\mathrm{Hg}$ species in New Hampshire.

\section{Materials and methods}

\subsection{Sampling sites}

This study utilizes data collected at three very different sites in the AIRMAP network which provide a geographical transect from rural, high-elevation terrestrial environments to the ocean (Fig. 1). Thompson Farm (TF) is located near the UNH campus in Durham, NH $\left(43.11^{\circ} \mathrm{N},-70.75^{\circ} \mathrm{W}, 24 \mathrm{~m}\right.$ elevation) and approximately $25 \mathrm{~km}$ from the Gulf of Maine. $\mathrm{TF}$ is a rural site, surrounded by mixed hardwood/pine forest and agricultural fields and is a key site for tracking regional pollution events in Northern New England (e.g., Mao and Talbot, 2004a, b; Fischer and Talbot, 2005; Talbot et al., 2005). Pac Monadnock (PM) $\left(42.86^{\circ} \mathrm{N},-71.88^{\circ} \mathrm{W}\right)$ is a heavily-forested site approximately $90 \mathrm{~km}$ inland near Peterborough, NH. PM is a high elevation site $(700 \mathrm{~m})$ and sits above the nocturnal inversion layer. In addition, we include measurements at the UNH site on Appledore Island (AI; $42.99^{\circ} \mathrm{N},-70.61^{\circ} \mathrm{W}$ ), located at the Shoals Marine Lab, Gulf of Maine. This site is $\sim 10 \mathrm{~km}$ offshore and uniquely situated for observing a wide variety of air masses, including from the open ocean, coastal marine and polluted continental environments (Mao et al., 2004b).

\subsection{Mercury measurements}

Continuous measurements of atmospheric $\mathrm{Hg}$ (initially as TGM) have been made since November 2003 at TF, and December of 2004 at PM. In 2006, RGM measurements were added at TF and PM in November and December, respectively. At $\mathrm{AI}, \mathrm{Hg}^{0}$ and RGM measurements were conducted during the warm season (May-October) of 2007. 
TGM is measured via cold vapor atomic florescence spectrophotometry (CVAFS) with a mercury vapor analyzer (model 2537A, Tekran, Inc.) at 5-min intervals and with a detection limit of $\sim 5-10$ ppqv $\left(1 \mathrm{ng} \mathrm{Hg} \mathrm{m}^{-3} \sim 112\right.$ ppqv at STP). Details of TGM measurements, including discussion of precision, accuracy and calibration, can be found in Mao et al. (2008). RGM is measured with a speciation unit (Tekran model 1130) consisting of a denuder and pump module installed upstream of the TGM analyzer. At TF and PM, the analyzer is housed in a temperature-controlled $\left(\sim 25^{\circ} \mathrm{C}\right)$ instrumentation shed. The denuder module is mounted on top of the shed at a height of approximately $5 \mathrm{~m}$. At AI, the denuder module is mounted at the top of a World War II-era observation tower $(\sim 20 \mathrm{~m})$, with the TGM analyzer installed inside the top floor.

The denuder module is attached to the pump module and TGM analyzer by a heated $\left(50^{\circ} \mathrm{C}\right)$ umbilical line. The $\mathrm{KCl}-$ coated denuder strips out RGM during a predetermined sampling period while the TGM analyzer continuously measures $\mathrm{Hg}^{0}$ (see Landis et al., 2002). Over the final $30 \mathrm{~min}$ of the sampling period, the denuder is flushed with zero air and heated to $500^{\circ} \mathrm{C}$ so that the RGM is thermally desorbed and sampled (as $\mathrm{Hg}^{0}$ ) by the TGM analyzer. Uncertainty of RGM measurements is high, especially at low levels, and we currently lack standard reference materials for calibration (Aspmo et al., 2005). To reduce uncertainty as much as possible, we strive for very low blanks. We measure RGM over a 2-h sampling period at a rate of $10 \mathrm{~L} \mathrm{~min}^{-1}$, and with a detection limit of $\sim 0.1 \mathrm{ppqv}$, based on three times the standard deviation of the average blank (e.g., $0.003 \pm 0.03$ ppqv, $n=3626$ at TF in 2007; Sigler et al., 2009).

Clean operation of the 1130 system is verified by flushing the system with zero air. Ideally, the resultant mixing ratio during zero air flushes before and after denuder heating is 0 ppqv. To ensure clean operation, the denuders, denuder module glassware, impactor frits and sample filters are replaced and cleaned on a 10-day basis at TF and PM, and typically on a 2-3 week basis at AI. At TF and especially AI, high humidity may corrode zero air canisters, saturate soda lime and lead to poor blanks or enhance cartridge passivation. To minimize the potential of moisture damage and improve blanks during desorption, the airstream leading into the 1130 pump module is cooled and dried using a custom-built refrigerator assembly and a canister of drierite. This system ensures that even when the drierite is exhausted, the relative humidity of the air entering the pump module is $\sim 25 \%$ or less. At AI, humidity as well as sea salts led to high blanks during the first month of deployment in 2007. Addition of the refrigerator assembly along with replacement of an aging pump diaphragm on 9 August resulted in clean blank values ( 0 ppqv) on more than $80 \%$ of the RGM observations at AI for the remainder of the field campaign.
In our experience, mixing ratios of 0 ppqv are achieved for $>99 \%$ of zero air flushes after desorption and for $>94 \%$ of zero air flushes immediately before desorption at both TF and PM. When a level of 0 ppqv is not achieved, a blank correction is made to the resultant RGM mixing ratio based on the average value of measurements obtained during zero air flushes before and after desorption.

\subsection{Supporting measurements}

Over 180 chemical species are measured at TF, including (and relevant to this study) $\mathrm{CO}, \mathrm{CO}_{2}, \mathrm{NO}, \mathrm{NO}_{\mathrm{y}}, \mathrm{O}_{3}$ and $\mathrm{SO}_{2}$. At $\mathrm{PM}$, a much more limited suite of species are measured, including $\mathrm{CO}, \mathrm{CO}_{2}, \mathrm{NO}$ and $\mathrm{O}_{3}$. Measurements at AI were limited to $\mathrm{CO}, \mathrm{CO}_{2}$ and $\mathrm{O}_{3}$. The calibration and measurement details for these gases can be found in previous studies for $\mathrm{O}_{3}$ and $\mathrm{CO}$ (Mao and Talbot, 2004a, b), $\mathrm{NO}$ and $\mathrm{NO}_{\mathrm{y}}$ (Mao and Talbot, 2004b) and $\mathrm{CO}_{2}$ (Talbot et al., 2005). $\mathrm{SO}_{2}$ is measured with a pulsed fluorescence analyzer (model 450C, Thermo Scientific Inc.). Standard meteorological measurements (Davis, Inc) including air temperature, pressure, relative humidity, wind speed and direction are measured at 1-min resolution at each site. All instruments are automated and controlled with National Instruments LabView hardware with custom software, and most data are available on-line in near real time (http://airmap.unh.edu).

\section{General characteristics}

Mean $\mathrm{Hg}^{0}$ mixing ratios of $161( \pm 30)$ and $157( \pm 21)$ ppqv were measured at TF and PM, respectively, from December 2006 to December 2007 (Table 1). These mean values are slightly lower than mean levels at other background sites in the Eastern US (i.e., Kim et al., 1995; VanArsdale et al., 2005; Sigler and Lee, 2006a). The difference in mean between the two sites is small (4 ppqv) but statistically significant $(p<0.01)$. At AI, mean $\mathrm{Hg}^{0}$ (July-September) was $139( \pm 31)$ ppqv, which is not significantly different from the means at both TF and PM during the same time period (Table 2), and somewhat lower than $\mathrm{Hg}^{0}$ measured at other coastal (e.g., $\sim 112-435$ ppqv, Malcolm et al., 2003; $\sim 200$ ppqv, Laurier and Mason, 2007) or oceanic sites (e.g., $\sim 280$ ppqv, Laurier et al., 2003).

Mean RGM mixing ratios at TF during 2007 were $0.41( \pm 0.93)$ ppqv and ranged from $0-22$ ppqv. RGM mixing ratios at PM were significantly $(p<0.01)$ lower than at $\mathrm{TF}$, with a mean of $0.13( \pm 0.25)$ ppqv and a median below the detection limit (0.1 ppqv). RGM mixing ratios at TF and PM were comparable to measurements at other rural locations in the Northeastern US (Han et al., 2004) and Southeastern Canada (Poissant et al., 2005). Approximately twothirds of all RGM observations at PM were below the detection limit, compared to $\sim 40 \%$ at TF. Mean RGM at AI during July-September was $0.76( \pm 0.88)$ ppqv, significantly higher 

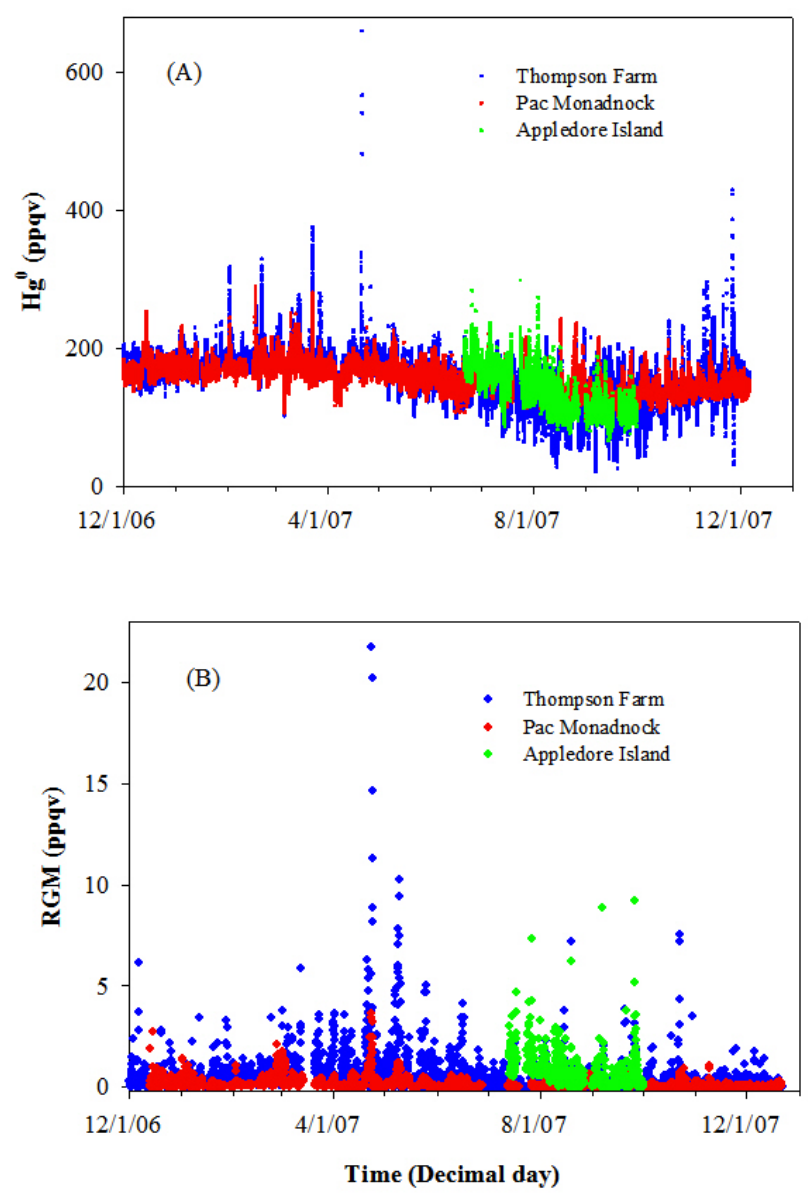

Fig. 2. Time series of (a) $\mathrm{Hg}^{0}$ (five-minute data) and (b) RGM (2-h sample time) at Thompson Farm, Pac Monadnock (December 2006-2007) and Appledore Island (June-September, 2007).

$(p<0.01)$ than at TF and PM during the same time period, and comparable to mean RGM measured at other oceanic sites (e.g., $\sim 0.6-1.0$ ppqv, Laurier et al., 2003; Laurier and Mason, 2007). At each site, the RGM mixing ratio represented $<1 \%$ of observed $\mathrm{Hg}^{0}$ on average during the study period, and was never higher than $11 \%$ at $\mathrm{TF}, 7 \%$ at $\mathrm{AI}$ and $3 \%$ at PM.

\subsection{Seasonal variation}

Time series of RGM and $\mathrm{Hg}^{0}$ mixing ratios at TF, PM and $\mathrm{AI}$ are shown in Fig. 2, and seasonal statistical summaries in Table 2. Seasonal variation in $\mathrm{Hg}^{0}$ was observed at $\mathrm{TF}$ and to a lesser extent at $\mathrm{PM}$, with higher mixing ratios in winter and lower in summer and fall (Table 2). Variation in seasonal means (Table 2$)$ was statistically significant $(p<0.01)$ at both sites. This seasonal pattern has been observed consistently since 2004 (Mao et al., 2008). The overall time series in $\mathrm{Hg}^{0}$ at both TF and PM are well-correlated $(r=0.77$, $p<0.01)$ except during summer $(r=0.4,0.1>p>0.05)$ when
Table 1. Statistical summary of $\mathrm{Hg}^{0}$ (5-min data) and RGM measurements at Thompson Farm, Pac Monadnock, and Appledore Island, 2007 (note that $1 \mathrm{ng} \mathrm{Hg} \mathrm{m}^{-3} \sim 112$ ppqv at STP).

\begin{tabular}{lccc}
\hline & & $\mathrm{Hg}^{0}$ (ppqv) & RGM (ppqv) \\
\hline Thompson & & & \\
Farm & Median & 164 & 0.15 \\
& Mean & 161 & 0.4 \\
& $\sigma$ & 30 & 0.9 \\
& Range & $21-660$ & $0-22$ \\
Pac & No. observations & 75717 & 4229 \\
Monadnock & & & \\
& Median & 157 & 0.05 \\
& Mean & 157 & 0.13 \\
& $\sigma$ & 21 & 0.3 \\
Appledore & Range & $98-289$ & $0-3.7$ \\
Island* & No. observations & 70319 & 3708 \\
& & & \\
& Median & 138 & 0.55 \\
& Mean & 139 & 0.76 \\
& $\sigma$ & 31 & 0.88 \\
& Range & $66-298$ & $0-8.8$ \\
& No. observations & 19298 & 608 \\
\hline
\end{tabular}

* Appledore Island data are summertime only.

$\mathrm{Hg}^{0}$ decreased significantly at TF (Fig. 2). As in other years, this is the only season in which $\mathrm{Hg}^{0}$ tends to be consistently higher at PM (Mao et al., 2008). The overall variation at PM was much smaller than that at TF, with higher minima ( $\sim 100$ ppqv) and rarely exceeding 250 ppqv. Precipitous day-to-day dips and peaks were accentuated during the warmer seasons at $\mathrm{TF}$ (note larger range in $\mathrm{Hg}^{0}$ mixing ratios in spring and summer, Table 2) while less variation in $\mathrm{Hg}^{0}$ occurred at PM, where standard deviation was lower (Table 2). This is mainly because, unlike the elevated site $\mathrm{PM}$, the strong nocturnal inversion in summer and fall at TF effectively inhibits the exchange between the surface and the free troposphere resulting in little replenishment of $\mathrm{Hg}^{0}$ from the regional pool above (Mao et al., 2008).

Previous observations at TF have suggested that marinederived halogen compounds (e.g., $\mathrm{CHBr}_{3}, \mathrm{CH}_{2} \mathrm{Br}_{2}, \mathrm{CH}_{3} \mathrm{I}$ ) may play a role in $\mathrm{Hg}$ chemistry at this coastal site (Zhou et al., 2005; Mao et al., 2008). Currently, our data are too limited to formally establish a link between seasonal variation of $\mathrm{Hg}$ speciation and levels of marine halogen compounds at TF. However, the pattern of significant decreases in $\mathrm{Hg}^{0}$ at TF during summer and an increase in the colder months (Fig. 2a) is repeatable from year to year at TF (see Mao et al., 2008) and we speculate that seasonal variation in halogen chemistry may play a role as higher levels of $\mathrm{CHBr}_{3}$ at TF during summer, accompanied by stronger photochemical 
Table 2. Seasonal statistical summary of $\mathrm{Hg}^{0}$ and RGM measurements at Thompson Farm and Pac Monadnock, 2007.

\begin{tabular}{lcccccccc}
\hline & \multicolumn{3}{c}{ Thompson Farm } & \multicolumn{5}{c}{ Pac Monadnock } \\
& Median & Mean & $\sigma$ & Range & Median & Mean & $\sigma$ & Range \\
\hline $\mathrm{Hg}^{0}$ (ppqv) & & & & & & & & \\
Winter & 181 & 182 & 18 & $102-330$ & 174 & 175 & 14 & $106-289$ \\
Spring & 173 & 172 & 23 & $99-660$ & 165 & 164 & 15 & $108-281$ \\
Summer & 143 & 139 & 28 & $21-217$ & 140 & 142 & 17 & $98-242$ \\
Fall & 144 & 144 & 28 & $31-430$ & 140 & 142 & 13 & $104-211$ \\
RGM (ppqv) & & & & & & & & \\
Winter & 0.25 & 0.4 & 0.5 & $0-6$ & 0.13 & 0.2 & 0.3 & $0-2.8$ \\
Spring & 0.3 & 0.8 & 1.6 & $0-22$ & 0.05 & 0.16 & 0.4 & $0-3.7$ \\
Summer & 0.01 & 0.2 & 0.5 & $0-7.2$ & 0.03 & 0.07 & 0.1 & $0-1$ \\
Fall & 0.07 & 0.2 & 0.5 & $0-7.6$ & 0.02 & 0.06 & 0.1 & $0-1$ \\
\hline
\end{tabular}

dissociation, could lead to lower $\mathrm{Hg}^{0}$ levels. On-going, yearround observations of $\mathrm{Hg}$ species at both $\mathrm{TF}$ and $\mathrm{AI}$ are intended to further examine this possible link.

Seasonal variation in RGM was also observed at TF and $\mathrm{PM}$, with larger mixing ratios in winter and early spring, and lower in summer, similar to $\mathrm{Hg}^{0}$. Season to season variation in mean RGM was significant $(p<0.01)$ at both sites, except from summer to fall at PM, when RGM was often not detected. At TF, monthly mean RGM increased from December through April, and decreased from April to July (Fig. 3), somewhat similar to trends observed at other rural locations (Kim et al., 1995; Poissant et al., 2005) and roughly the inverse of the monthly mean temperature trend (not shown). This may suggest the influence of local and regional RGM emissions from combustion sources related to wintertime heating (see Sect. 4) and slower removal processes on RGM measurements at TF, as well as meteorological factors or photochemical production from high biogenic emissions of $\mathrm{Hg}^{0}$ in early spring (see Sect. 5.1).

A contrary pattern of higher RGM in warmer months than colder months has been observed in studies conducted near urban areas or significant point combustion sources (e.g., Lindberg and Stratton, 1998; Liu et al., 2007) and is possibly explained by differing seasonal variation of atmospheric oxidants, removal processes and/or point source emissions. Small (compared to TF) but significant $(p<0.01)$ seasonal variation in RGM was observed at PM (Table 2, Fig. 4). Similar to TF, higher RGM was observed at PM in winter and spring, although mean monthly RGM peaked in February (not shown) as opposed to April at TF. In summer and fall, very little RGM was present at PM, as the median and mean mixing ratios (Table 2) as well as approximately $80 \%$ of all instantaneous measurements were below the detection limit, compared with $10 \%$ for winter and spring. Absence of RGM at PM during summer and fall may reflect negligible contribution from large combustion sources in the region, or enhanced removal processes. Little correlation was

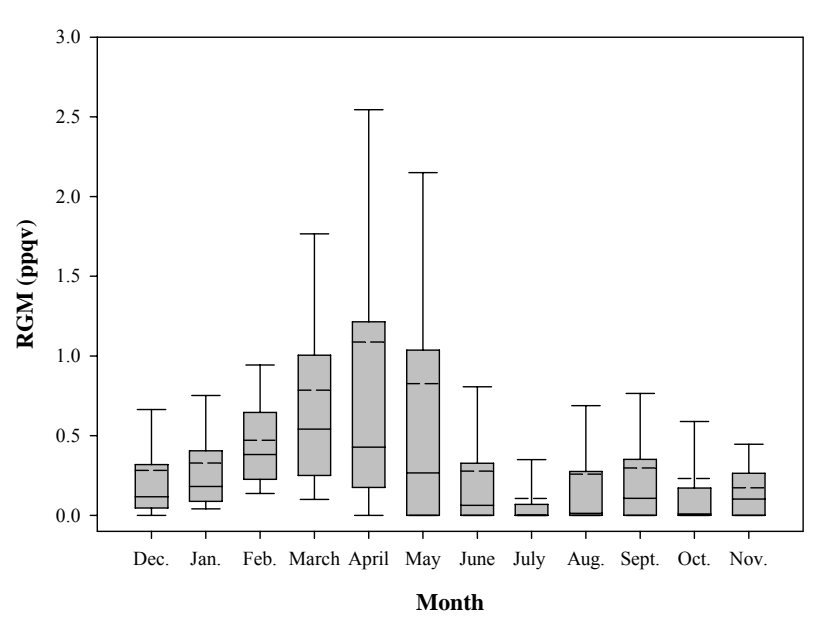

Fig. 3. Monthly variation in RGM at Thompson Farm. The solid lines within each box represent the median mixing ratio, dashed line represents the mean, boundaries of the box represent 25th and 75th percentile, and whiskers indicate 10th and 90th percentile.

observed between RGM mixing ratios at both sites except during spring $(r=0.75, p<0.01)$ when that correlation was strongly driven by several large events.

\subsection{Diurnal variation}

Seasonally averaged daily cycles of both $\mathrm{Hg}^{0}$ and RGM at TF indicate clear diurnal patterns in summer-fall and less pronounced ones in winter-spring (Fig. 4a, c) in contrast to virtually no diurnal variability year-round at $\mathrm{PM} . \mathrm{Hg}^{0}$ mixing ratios at $\mathrm{TF}$ tend to decrease at night to a minimum just before sunrise, and then increase significantly through mid-afternoon, similar to diurnal cycles observed elsewhere (Kellerhals et al., 2003; Kim et al., 2005, Poissant et al., 2005). This pattern is especially pronounced during summer, when the mean amplitude of the diurnal $\mathrm{Hg}^{0}$ profile 

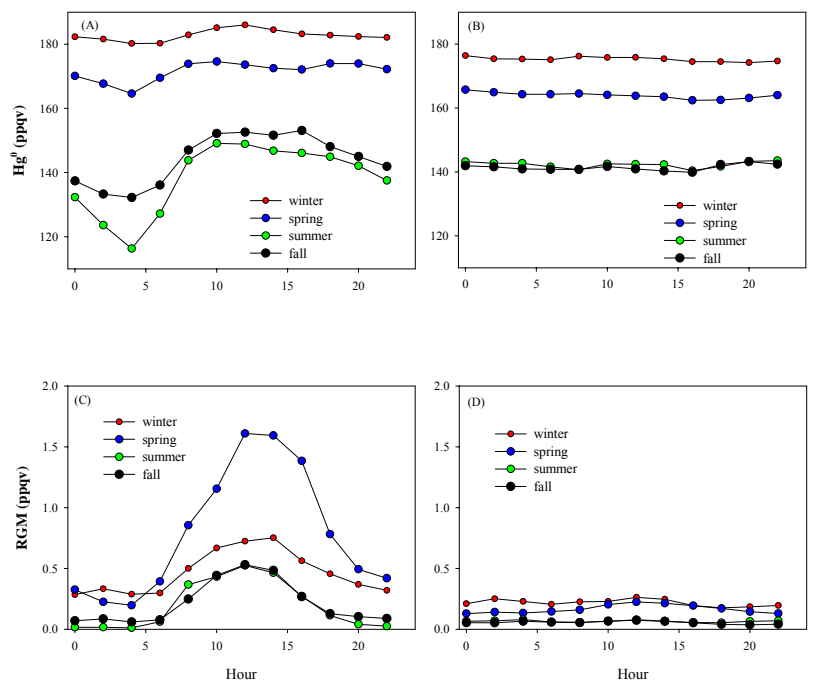

Fig. 4. Seasonally averaged diurnal profiles of $\mathrm{Hg}^{0}$ (two-hour averages) and RGM at Thompson Farm (a, c) and Pac Monadnock (b, d) during 2007. Time is EST.

was $\sim 32$ ppqv (compared to 12 and 7 ppqv during spring and winter, respectively) and was more pronounced than during the summers of 2004-2006 (20-25 ppqv, Mao et al., 2008). As aforementioned, the significant decline in $\mathrm{Hg}^{0}$ at night is largely attributable to dry deposition under nocturnal inversions without replenishment from the regional air above, which is a common feature at low elevation sites in New England during summer and fall (Talbot et al., 2005; Mao et al., 2008).

RGM at TF (Fig. 4c) follows a diurnal pattern that approximates the diurnal trends in temperature and solar radiation (Sect. 5.1), similar to the finding from a Maryland coastal site in Laurier et al. (2007). Diurnal RGM variation was significant, ranging from $\sim 0.5$ (winter, summer, fall) to $1.4 \mathrm{ppqv}$ (spring) and typically peaked at midday (12:00-14:00 EST) with seasonal daily maxima ranging from $\sim 0.5 \mathrm{ppqv}$ (summer/fall) to $1.6 \mathrm{ppqv}$ (spring). RGM was minimal at night, typically below the detection limit during summer and fall, likely as a result of dry deposition and little production. Rapid increase in RGM during the morning likely reflects downward convective mixing and photochemical production.

At PM, diurnal patterns in both $\mathrm{Hg}^{0}$ and $\mathrm{RGM}$ were largely absent (Fig. 4b, d), because the high-elevation site is above the nocturnal inversion layer at night and in the convective boundary layer during the day and thus constantly samples regional air. Although RGM peaks at PM may be attributable to sparse local or regional combustion sources, photochemical production and general contributions from anthropogenic sources appear to be minimal, and RGM is rarely detectable during summer and fall. This likely reflects the sites' distance from major combustion source areas as well as marine-derived halogens, which can lead to photo-

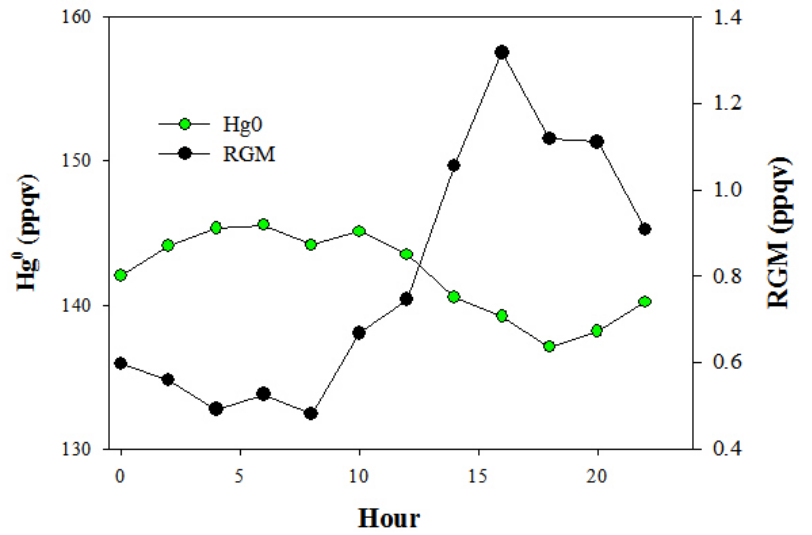

Fig. 5. Average diurnal profiles of $\mathrm{Hg}^{0}$ (two-hour averages) and RGM at Appledore during summer 2007. Time is EST.

chemical production of RGM. The distinct diurnal pattern in $\mathrm{Hg}^{0}$ at AI during summer 2007 (Fig. 5) was different from that observed at $\mathrm{TF}$ (Fig. 4c). At AI, $\mathrm{Hg}^{0}$ reaches peak values during the early morning and then decreases throughout the day to a minimum in the late afternoon, and then steadily increases at night. Also, daytime $\mathrm{Hg}^{0}$ mixing ratios in the MBL were slightly suppressed relative to the inland sites, as mean mixing ratios in late afternoon $(\sim 16: 00-18: 00 \mathrm{EST})$ at AI were $\sim 8$ ppqv and 5 ppqv lower on average than those at TF and $\mathrm{PM}$, respectively. $\mathrm{Hg}^{0}$ variation over the day $(\sim 8 \mathrm{ppqv})$ was much less than at TF. RGM at AI was typically anticorrelated with $\mathrm{Hg}^{0}$, reaching peak mixing ratios in the late afternoon, roughly coincident with the diurnal minimum of $\mathrm{Hg}^{0}$ (Fig. 5). The diurnal cycle of $j \mathrm{NO}_{2}$ at $\mathrm{AI}$ (see Sect. 5.1) was also opposite in phase with that of $\mathrm{Hg}^{0}$. This suggests a significant daytime sink of $\mathrm{Hg}^{0}$ and source of RGM which is more significant than at TF and PM and likely arises from photochemical oxidation in the presence of marine-derived halogen species (e.g., $\mathrm{BrO}, \mathrm{Cl}^{-}, \mathrm{Br}^{-}, \mathrm{Cl}_{2}, \mathrm{Br}_{2}, \mathrm{BrCl}$ ), possibly resulting in more efficient loss of $\mathrm{Hg}$ than at inland sites (Pszenny et al., 1993; Knipping et al., 2000; Mason and Sheu, 2002; Laurier et al., 2003). In the MBL, halogen radicals are the primary $\mathrm{Hg}^{0}$ oxidants, and their ambient levels are light-dependent. For example, the mixing ratio of $\mathrm{BrO}$ in the mid-latitude MBL reportedly varies from $\sim 1 \mathrm{pptv}$ at night to $\sim 6 \mathrm{pptv}$ in the first hours after sunrise followed by a secondary maximum around noon and is light- and wind speed-dependent (Saiz-Lopez et al., 2006). Previous measurements at $\mathrm{AI}$ revealed significant levels of marine halogen compounds (e.g., $\mathrm{CHBr}_{3}, \mathrm{CH}_{2} \mathrm{Br}_{2}$ ) which can be photolyzed over periods of days to weeks (Zhou et al., 2005, 2008). The presence of these compounds at TF (Zhou et al., 2005, 2008), at times in significant quantities (e.g., Sigler et al., 2009), as well as the somewhat similar $\mathrm{Hg}^{0}$ levels and $\mathrm{Hg}^{0}-\mathrm{CO}$ ratios at TF and AI seems to suggest that similar air mass characteristics are often observed at these sites. Not only does 


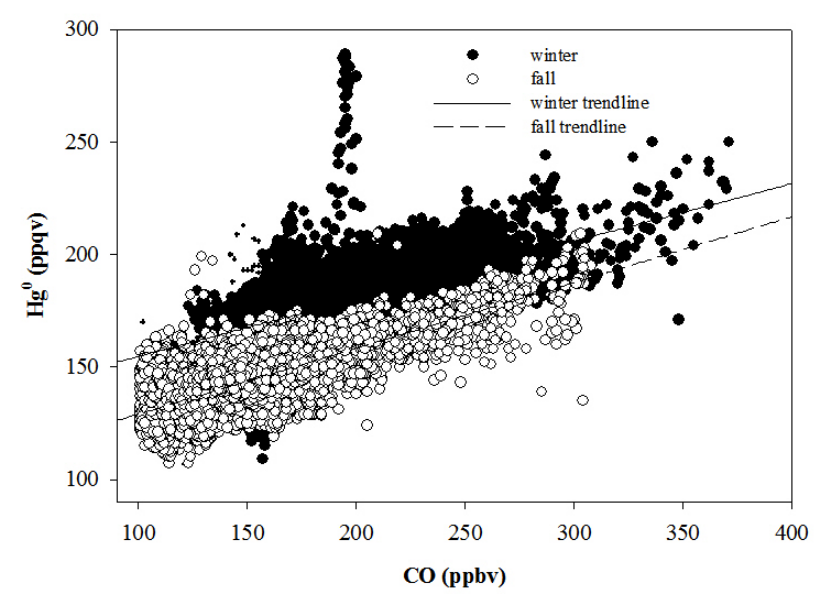

Fig. 6. $\mathrm{Hg}^{0}-\mathrm{CO}$ relationships at $\mathrm{PM}$ during winter $(\mathrm{y}=0.256 \mathrm{x}+129.1, \quad r=0.63)$ and fall $(\mathrm{y}=0.292 \mathrm{x}+100, \quad r=0.75)$, 2007. Data are 5-min averages.

polluted continental air impact AI, but maritime air masses may have an impact on $\mathrm{Hg}$ cycling at TF.

The diurnal amplitude of RGM was $0.8 \mathrm{ppqv}$, while the amplitude for $\mathrm{Hg}^{0}$ was $\sim 8$ ppqv (Fig. 5). Previous studies have suggested that in the MBL, a significant amount of $\mathrm{Hg}^{0}$ is oxidized to RGM and further to particulate $\mathrm{Hg}\left(\mathrm{Hg}^{P}\right)$ during the day (Laurier and Mason, 2007; Malcolm et al., 2003). If indeed the loss of $\mathrm{Hg}^{0}$ over the day was the gain of RGM, then the large discrepancy of the diurnal amplitude between the two implies the rapid removal of RGM to sea salt aerosols and the ocean surface.

\section{Relationship of $\mathrm{Hg}$ species with key trace gases}

The relationships of $\mathrm{Hg}^{0}$ with $\mathrm{CO}$ and $\mathrm{CO}_{2}$ at $\mathrm{TF}$ and $\mathrm{PM}$ for previous years were documented and discussed by Mao et al. (2008), and observations from 2007 largely reinforce those findings. Briefly, $\mathrm{Hg}^{0}$ was well-correlated ( $r$-value ranging from 0.46 (spring) to 0.75 (fall), $p<0.01$ ) with carbon monoxide (CO) at PM during 2007 (Fig. 6 shows regressions for winter and fall, which represented minimum and maximum emission ratios during 2007). During wintertime, when biogenic impact on carbon and $\mathrm{Hg}^{0}$ is minimal, the $\mathrm{Hg}^{0}-\mathrm{CO}$ ratio at $\mathrm{PM}$ is taken as representative of regional anthropogenic influence. The ratio derived for winter $2007\left(\sim 0.26 \mathrm{fmol} \mathrm{nmol}^{-1}, r=0.63, p<0.01\right)$ was similar to previous years (Mao et al., 2008) suggesting fairly consistent regional anthropogenic contribution from year-to-year. The $\mathrm{Hg}^{0}-\mathrm{CO}$ ratio at $\mathrm{PM}$ was also very consistent from season to season, varying by no more than $\sim 10 \%$, suggesting little seasonal variation in regional anthropogenic influence (Fig. 6).

$\mathrm{Hg}^{0}$ was correlated with $\mathrm{CO}_{2}$ at PM $(r=0.27-0.59$, $p<0.01)$, particularly during winter $(r=0.59, p<0.01)$ (not shown). This $\mathrm{Hg}^{0}-\mathrm{CO}_{2}$ ratio $\left(\sim 1.8 \mathrm{fmol} \mu \mathrm{mol}^{-1}\right)$ can also be used as a tracer for regional anthropogenic contribution (e.g., Sigler and Lee, 2006a) as biogenic impacts on $\mathrm{CO}_{2}$ are minimal. As a rough comparison, we estimated total annual $\mathrm{Hg}$ emission of approximately 6 tons and 8.5 tons for $\mathrm{CO}$ and $\mathrm{CO}_{2}$, respectively, which are of similar magnitude using the wintertime $\mathrm{Hg}^{0}-\mathrm{CO}$ and $\mathrm{Hg}^{0}-\mathrm{CO}_{2}$ slope values with total emissions of $\mathrm{CO}_{2}\left(\sim 1.28 \times 10^{8} \mathrm{Mg}\right.$, EPA, 2008a) and CO $\left(\sim 3.11 \times 10^{6} \mathrm{Mg}\right.$, EPA, 2008b) from states (NH, ME, MA, VT) in the regional air shed (e.g., Sigler and Lee, 2006a).

Compared to $\mathrm{PM}$, the wintertime $\mathrm{Hg}^{0}$-CO relationship at TF was much weaker with $r$ - and the slope values lower by nearly a factor of two $\left(\sim 0.14 \mathrm{fmol} \mathrm{nmol}^{-1}\right)$ likely owing to local sources (Mao and Talbot, 2004b; Mao et al., 2008). $\mathrm{Hg}^{0}$ was positively correlated with $\mathrm{CO}_{2}$ during wintertime at TF $(r=0.37, p<0.01)$ due to dominant anthropogenic contribution and minimal biological biogenic influence.

The strength of the $\mathrm{Hg}^{0}$-CO relationship at AI during summer $(r=0.33, p<0.01)$ was intermediate between TF and PM, while the ratio $\left(0.16 \mathrm{fmol} \mathrm{nmol}^{-1}\right)$ was closer to those observed at TF. Compared to PM, the more diffuse relationship at TF and AI is likely due to the interference of other possible processes, such as stronger oxidation of $\mathrm{Hg}^{0}$ and oceanic emissions, and the proximity of the two sites (Mao et al., 2008). The stronger $\mathrm{Hg}^{0}-\mathrm{CO}$ relationship at $\mathrm{AI}$ than at TF indicates that the site, despite being oceanic, is under anthropogenic influence from several anthropogenic source regions (Mao and Talbot, 2004a).

$\mathrm{SO}_{2}$ and $\mathrm{Hg}$ species are co-emitted from combustion sources, and a significant correlation between these two species might be expected at a rural or urban site subject to anthropogenic influences (e.g., Carpi, 1997). Measurements at TF suggested a more pronounced RGM-SO $\mathrm{SO}_{2}$ correlation, particularly during summer (Table 3 ), at $\mathrm{SO}_{2}$ mixing ratios $>2$ ppbv, which indicates that the correlation is primarily controlled by a small number of enhanced $\mathrm{SO}_{2}$ events. This is similar to previous studies in rural (Manolopoulos et al., 2007a), urban (Liu et al., 2007) and coastal sites (Engle et al., 2008) in the US and indicates, in part, local or regional transport of RGM and $\mathrm{SO}_{2}$ directly emitted by anthropogenic sources or chemical conversion of $\mathrm{Hg}^{0}$ within pollution plumes. The likely influence of anthropogenic sources is underscored by the tendency for enhanced mixing ratios of both species under south-southwesterly to westerly flow (see Sect. 5.3) which transports air masses from the northeastern urban corridor. $\mathrm{Hg}^{0}$ was poorly correlated with $\mathrm{SO}_{2}$ at $\mathrm{TF}$, except during wintertime $(r=0.43, p<0.01)$, likely reflecting the longer lifetime of $\mathrm{SO}_{2}$ in winter (Mao et al., 2008).

The relationship between atmospheric ozone $\left(\mathrm{O}_{3}\right)$ and $\mathrm{Hg}$ species is unclear. $\mathrm{O}_{3}$ may act as an oxidant of $\mathrm{Hg}^{0}$ to $\mathrm{RGM}$, particularly in urban locations or with photochemically processed air masses (Lynam and Keeler, 2005) or may play an indirect role in the conversion of $\mathrm{Hg}^{0}$ to RGM in Arctic environments (e.g., Lindberg et al., 2002). Han et al. (2004) indicated no clear relationship between $\mathrm{Hg}$ species and $\mathrm{O}_{3}$. 
Table 3. Correlation coefficients $(r)$ for $\mathrm{Hg}^{0}$ and RGM with selected trace gases, 2007. $\mathrm{Hg}^{\mathrm{O}}$ correlations are five-minute averages, RGM are two-hour averages, $n=$ number of observations $\left({ }^{*} p<0.01\right)$.

\begin{tabular}{|c|c|c|c|c|}
\hline & \multicolumn{3}{|c|}{ Thompson Farm } & \multirow{2}{*}{$\begin{array}{c}\begin{array}{c}\text { Pac } \\
\text { Monadnock }\end{array} \\
\mathrm{O}_{3}\end{array}$} \\
\hline & $\mathrm{SO}_{2}$ & $\mathrm{O}_{3}$ & $\mathrm{NO}_{\mathrm{y}}$ & \\
\hline \multicolumn{5}{|l|}{$\mathrm{Hg}^{0}$} \\
\hline Winter & $\begin{array}{c}0.4^{*} \\
(n=17970)\end{array}$ & $\begin{array}{c}0 \\
(n=19387)\end{array}$ & $\begin{array}{c}0.5^{*} \\
(n=15953)\end{array}$ & $\begin{array}{c}-0.1 \\
(n 16705)\end{array}$ \\
\hline Spring & $\begin{array}{c}0.1 \\
(n=18562)\end{array}$ & $\begin{array}{c}0.3^{*} \\
(n=18228)\end{array}$ & $\begin{array}{c}0.3^{*} \\
(n=17267)\end{array}$ & $\begin{array}{c}0.2^{*} \\
(n=18744)\end{array}$ \\
\hline Summer & $\begin{array}{c}0.1^{*} \\
(n=18935)\end{array}$ & $\begin{array}{c}0.5^{*} \\
(n=19395)\end{array}$ & $\begin{array}{c}0.2^{*} \\
(n=18825)\end{array}$ & $\begin{array}{c}0.5^{*} \\
(n=15262)\end{array}$ \\
\hline Fall & $\begin{array}{c}0.1^{*} \\
(n=15976)\end{array}$ & $\begin{array}{c}0.3^{*} \\
(n=18950)\end{array}$ & $\begin{array}{c}0.3^{*} \\
(n=18904)\end{array}$ & $\begin{array}{c}-0.1 \\
(n=19457)\end{array}$ \\
\hline RGM & & & & \\
\hline Winter & $\begin{array}{c}0.5^{*} \\
(n=1119)\end{array}$ & $\begin{array}{c}0.3^{*} \\
(n=1139)\end{array}$ & $\begin{array}{c}0.1 \\
(n=1008)\end{array}$ & $\begin{array}{c}0.1^{*} \\
(n=1073)\end{array}$ \\
\hline Spring & $\begin{array}{c}0.3^{*} \\
(n=1060)\end{array}$ & $\begin{array}{c}0.6^{*} \\
(n=1000)\end{array}$ & $\begin{array}{c}0.1^{*} \\
(n=995)\end{array}$ & $\begin{array}{c}0.5^{*} \\
(n=1046)\end{array}$ \\
\hline Summer & $\begin{array}{c}0.8^{*} \\
(n=1095)\end{array}$ & $\begin{array}{c}0.4^{*} \\
(n=1076)\end{array}$ & $\begin{array}{c}0.2^{*} \\
(n=1095)\end{array}$ & $\begin{array}{c}0.2^{*} \\
(n=770)\end{array}$ \\
\hline Fall & $\begin{array}{c}0.7^{*} \\
(n=952)\end{array}$ & $\begin{array}{c}0.4^{*} \\
(n=1068)\end{array}$ & $\begin{array}{c}0.04 \\
(n=827)\end{array}$ & $\begin{array}{c}0.4^{*} \\
(n=1043)\end{array}$ \\
\hline
\end{tabular}

Our measurements revealed a diffuse but positive correlation between $\mathrm{Hg}^{0} / \mathrm{RGM}$ and $\mathrm{O}_{3}$ at TF and PM in 2007 (Table 3). RGM generally was better correlated with $\mathrm{O}_{3}$ than was $\mathrm{Hg}^{0}$, which is not surprising given the levels of $\mathrm{Hg}^{0}$ (two orders of magnitude larger than RGM) and therefore relatively small reduction due to oxidation. Moreover, although $\mathrm{O}_{3}$ is an oxidant of $\mathrm{Hg}^{0}$ and may contribute in some way to local RGM levels, the reaction is possibly too slow to be of primary importance to daytime RGM production compared to halogen radicals (e.g., Malcolm et al., 2003; Calvert and Lindberg, 2005; Mao et al., 2008).

At TF, RGM was most strongly correlated with $\mathrm{O}_{3}$ during spring and more weakly during winter. $\mathrm{Hg}^{0}$ also showed stronger correlation with $\mathrm{O}_{3}$ during the warmer months and was not correlated during the winter (Table 3). A somewhat similar trend was observed at PM although the correlations were generally weaker. The stronger $\mathrm{Hg}^{0}-\mathrm{O}_{3}$ relationship during summer likely reflects not only light-dependence of both $\mathrm{O}_{3}$ and $\mathrm{Hg}^{0}$ during the day (see Sect. 5.1) but, perhaps more significantly, similar nighttime depositional loss under a stable nocturnal boundary layer (Mao et al., 2008). This is further verified by the stronger correlation $(r=0.7$, compared to $r=0.5$ for all data, Table 3 ) between $\mathrm{Hg}^{0}$ and $\mathrm{O}_{3}$ during the early morning hours (03:00-07:00 EST).

The positive $\mathrm{RGM}-\mathrm{O}_{3}$ correlation, particularly during warmer periods, is similar to those reported for both ur- ban (Lynam and Keeler, 2005) and rural locations subject to anthropogenic influence (Han et al., 2004; Yatavelli et al., 2006). This correlation seems to reflect similarly strong light-dependence as both species tend to peak in early to midafternoon. At AI, $\mathrm{O}_{3}$ was weakly correlated with both $\mathrm{Hg}^{0}$ $(r=0.26, p<0.01)$ and RGM $(r=0.36, p<0.01)$. In the marine boundary layer, $\mathrm{O}_{3}$ can be both destroyed and produced through reactions involving halogen compounds. The weak, positive correlation between $\mathrm{Hg}^{0}$ and $\mathrm{O}_{3}$ at $\mathrm{AI}$ could reflect their oxidation by halogen radicals, which has also been postulated to play an important role at TF (Mao et al., 2008).

Relationships between reactive nitrogen species $\left[\mathrm{NO}_{\mathrm{y}}=\mathrm{NO}_{\mathrm{x}}+\mathrm{PAN}+\mathrm{HNO}_{3}+\mathrm{NO}_{3}+\ldots\right]$ and $\mathrm{Hg}$ can also be used to identify the anthropogenic contribution (Mao et al., 2008). This is because one of the main $\mathrm{NO}_{\mathrm{y}}$ components, $\mathrm{NO}_{\mathrm{x}}$, as with $\mathrm{SO}_{2}$, may be co-emitted with mercury from combustion sources (e.g., Carpi, 1997) and the majority of it is quickly converted to other reactive nitrogen species. The $\mathrm{TF}$ measurements suggested weak correlation of $\mathrm{NO}_{\mathrm{y}}$ with $\mathrm{Hg}^{0}$, particularly during winter (Table 3). The $\mathrm{Hg}^{0}-\mathrm{NO}_{\mathrm{y}}$ relationship at $\mathrm{TF}$, also observed in previous years as described by Mao et al. (2008), is driven mainly by similar nighttime depositional loss, as loss of $\mathrm{NO}_{\mathrm{y}}$ is driven by fast deposition of $\mathrm{HNO}_{3}$ and $\mathrm{N}_{2} \mathrm{O}_{5}$. The $\mathrm{Hg}^{0}-\mathrm{NO}_{\mathrm{y}}$ ratio was much higher during the warmer months $\left(2.59 \mathrm{fmol} \mathrm{nmol}^{-1}\right.$ in spring, $2.42 \mathrm{fmol} \mathrm{nmol}^{-1}$ in summer) than during winter $\left(1.05 \mathrm{fmol} \mathrm{nmol}^{-1}\right)$ and fall $\left(1.76 \mathrm{fmol} \mathrm{nmol}^{-1}\right)$. This may also reflect high solubility and nighttime loss of $\mathrm{NO}_{\mathrm{y}}$ species $\left(\mathrm{HNO}_{3}, \mathrm{PAN}, \mathrm{N}_{2} \mathrm{O}_{5}\right)$ during the warmer months when dew frequently forms or enhanced anthropogenic emission of $\mathrm{NO}_{\mathrm{x}}$ during winter.

The lifetime of $\mathrm{NO}_{\mathrm{y}}$ and $\mathrm{RGM}$ is too different for the two species to be significantly related in the atmosphere, which was confirmed by the very weak correlation $(r<0.2)$. However, in summer there was a weak positive correlation between the two species, likely due to dry depositional loss at night. Moreover, during nighttime hours (18:00-08:00 EST), RGM and $\mathrm{NO}_{\mathrm{y}}$ showed a stronger, though still weak, positive relationship ( $r$-value ranging from $0.14, p<0.01$ in winter to $0.3, p<0.01$ in summer). Overall, these relationships suggest dry deposition is a common loss mechanism for $\mathrm{NO}_{\mathrm{y}}, \mathrm{RGM}$ and $\mathrm{Hg}^{0}$ at night and highly different chemical sources and sinks during the day.

\section{Relationship of $\mathrm{Hg}$ species with selected meteorologi- cal variables}

\subsection{Temperature}

Instantaneous RGM and $\mathrm{Hg}^{0}$ measurements showed no correlation with temperature when regressed over all of 2007. However, the relationship was more pronounced over shorter time scales. In the case of $\mathrm{Hg}^{0}$, the correlation with temperature was progressively stronger over 10, 20 and 30-day 
Table 4. Correlation coefficients $(r)$ for $\mathrm{Hg}^{0}$ and RGM with relative humidity (daytime only) and air temperature, 2007. $\mathrm{Hg}^{0}$ correlations are five-minute averages, RGM are two-hour averages, $n=$ number of observations $\left({ }^{*} p<0.01\right)$.

\begin{tabular}{lcccc}
\hline & \multicolumn{2}{c}{ Thompson Farm } & \multicolumn{2}{c}{ Pac Monadnock } \\
\hline & $T_{\text {air }}$ & $\mathrm{RH}$ & $T_{\text {air }}$ & $\mathrm{RH}$ \\
\hline $\mathrm{Hg}^{0}$ & & & & \\
Winter & $0.4^{*}$ & $0.2^{*}$ & $0.4^{*}$ & $0.2^{*}$ \\
& $(n=19387)$ & $(n=19387)$ & $(n=16705)$ & $(n=16705)$ \\
Spring & 0 & $0.1^{*}$ & 0 & $0.1^{*}$ \\
& $(n=19473)$ & $(n=19473)$ & $(n=18746)$ & $(n=18746)$ \\
Summer & $0.5^{*}$ & $0.2^{*}$ & $0.5^{*}$ & $0.3^{*}$ \\
& $(n=19524)$ & $(n=19762)$ & $(n=16363)$ & $(n=16363)$ \\
Fall & $0.1^{*}$ & $0.2^{*}$ & 0 & $0.3^{*}$ \\
& $(n=18975)$ & $(n=18975)$ & $(n=20018)$ & $(n=20018)$ \\
RGM & & & & \\
Winter & $0.2^{*}$ & $-0.4^{*}$ & $0.2^{*}$ & $-0.3^{*}$ \\
& $(n=1139)$ & $(n=1139)$ & $(n=1073)$ & $(n=1073)$ \\
Spring & $0.3^{*}$ & $-0.5^{*}$ & $0.2^{*}$ & $-0.5^{*}$ \\
& $(n=1069)$ & $(n=1060)$ & $(n=1046)$ & $(n=1046)$ \\
Summer & $0.3^{*}$ & $-0.3^{*}$ & 0 & $-0.3^{*}$ \\
& $(n=1083)$ & $(n=1095)$ & $(n=825)$ & $(n=925)$ \\
Fall & $0.3^{*}$ & $-0.3^{*}$ & $0.2^{*}$ & $-0.4^{*}$ \\
& $(n=1068)$ & $(n=1068)$ & $(n=1068)$ & $(n=1068)$ \\
\hline & & & &
\end{tabular}

moving averages (not shown), suggesting that processes on monthly to seasonal time scales impact the $\mathrm{Hg}$-temperature relationship. Therefore, we examined the relationship on seasonal and diurnal time scales. RGM was weakly correlated with ambient temperature at TF in all seasons and during winter and fall at $\mathrm{PM}$, while $\mathrm{Hg}^{0}$ was significantly correlated with temperature during spring and fall at both sites (Table 4). These observations are generally consistent with those reported for other rural sites in North America (Han et al., 2004; Poissant et al., 2005). Diurnally, RGM and $\mathrm{Hg}^{0}$ were both related to the diurnal temperature trend at $\mathrm{TF}$, and the relationships vary significantly among seasons (Fig. 7). We note that in the case of RGM (Fig. 7b), the diurnal variation is better explained using an exponential rather than a linear function. This is similar to exponential relationships describing TGM desorption from soil (Sigler and Lee, 2006b) and may further substantiate a thermal mechanism. In general, these observations suggest that the seasonal change in solar angle plays an important role in the variation in $\mathrm{Hg}^{0}$ and RGM mixing ratios at TF.

Rather than suggesting a direct thermal impact of temperature on RGM production, the correlation between $\mathrm{RGM} / \mathrm{Hg}^{0}$ and temperature may imply that these variables are both primarily driven by solar radiation. Specifically, in rural coastal regions $\mathrm{RGM}$ is produced as a result of $\mathrm{Hg}^{0}$ oxidation by halogen radicals that are generated through photochemical processes and photosynthesis in sea water, which are likely
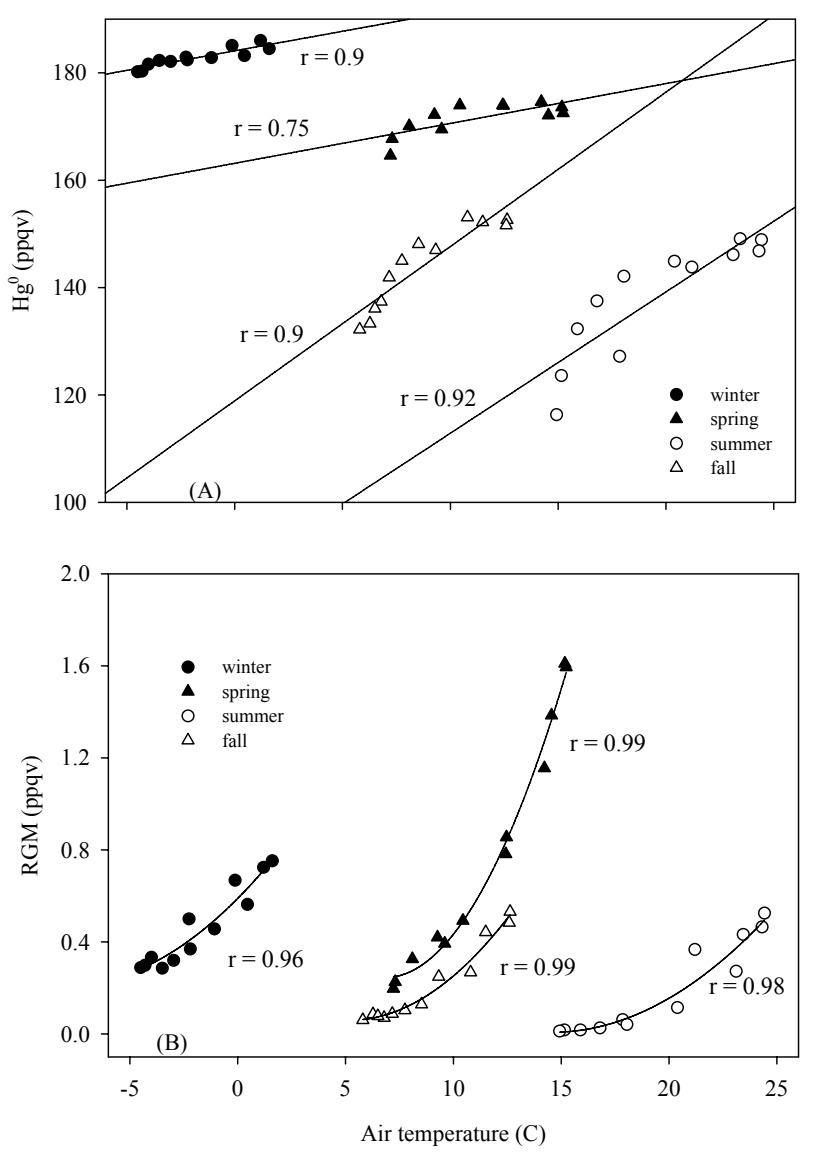

Fig. 7. Regressions of seasonal mean hourly (a) $\mathrm{Hg}^{0}$ and (b) RGM with air temperature at TF, 2007. Data are two-hour averages and are extracted from the same data used in temperature correlations in Table 4.

present in significant levels at TF (Mao et al., 2008). This is further substantiated by the strong similarity between time series of RGM and $j \mathrm{NO}_{2}$ (Fig. 8), particularly during summer. With regard to the high $\mathrm{Hg}$ levels at warmer temperatures, it may result from thermally and/or photochemically mediated release from soil (e.g., Poissant and Casimir, 1998; Sigler and Lee, 2006b). For example, although typical daytime $\mathrm{Hg}^{0}$ mixing ratios were $170-175$ ppqv in Spring (Fig. 4), mixing ratios exceeding 200 ppqv during the daytime were common during the first warm and dry period of the year ( $\sim 20$ April and extending into June). This may suggest enhanced emission of $\mathrm{Hg}$ from soils and vegetation (Lindberg et al., 1992; Lindberg et al., 1998; Sigler and Lee, 2006b).

The significant relationship between hourly mean RGM and $\mathrm{Hg}^{0}$ with temperature observed at $\mathrm{TF}$ was not observed at AI during summer (not shown), although this may be influenced by the smaller diurnal temperature variation as well as the significant daytime decrease in $\mathrm{Hg}^{0}$ (Fig. 5). However, absolute RGM and $\mathrm{Hg}^{0}$ mixing ratios were weakly correlated 


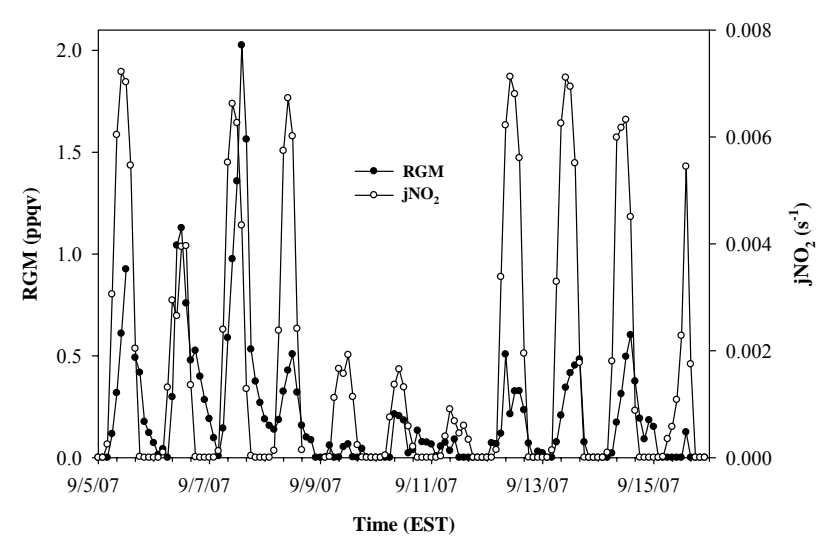

Fig. 8. Time series of $j \mathrm{NO}_{2}$ and $\mathrm{RGM}$ at Thompson Farm during selected period in September 2007. Data are two-hour averages.

with temperature $(r \sim 0.2, p<0.01)$. RGM was correlated $(r=0.3, p<0.01)$ with $j \mathrm{NO}_{2}$ at AI, reflecting photochemical production of RGM during the afternoon.

\subsection{Relative humidity}

The diurnal pattern of RGM (Fig. 4) is opposite in phase of that for relative humidity (RH) at TF and PM, which is relatively high and consistent at night ( $>90 \%$ during summer at TF), when RGM is quickly lost by deposition. During the daytime at all sites, RH varies significantly depending on local weather conditions (RH is typically $100 \%$ during precipitation events). To better elucidate potential impact of humidity on RGM mixing ratios, we exclusively examined daytime observations.

A significant, negative relationship of RGM with RH was observed during the daytime at all three sites in 2007 (Table 4). In summer, the negative relationship at AI ( $r=-0.35$, $p<0.01)$ was of similar strength as those observed at PM and TF (Table 4$)$, despite smaller diurnal variation $(\sim 15 \%$, compared to $\sim 40 \%$ at TF and $25 \%$ at PM) and a different diurnal pattern (RH tends to peak at 08:00-10:00 EST at AI, rather than during the night). A significant contributing factor to this relationship appears to be the nearly complete washout of RGM during rain events (see Sigler et al., 2009). Very low levels of RGM have previously been observed during rain events in both continental (Yatavelli et al., 2006) and marine atmospheres (Laurier et al., 2007). AT TF in 2007, mean RGM during rain events was $\sim 0.07 \pm 0.14$ ppqv ( $n=337$, median/mode $=0$ ppqv) which is below the detection limit of the instrumentation. This is owed to the high solubility of RGM and therefore its efficient removal from the atmosphere by wet precipitation.

Our data also suggest differences in this removal mechanism depending on precipitation type. In fact, during snow events at TF in 2007, not only was RGM not removed but was on average slightly higher $(0.48 \pm 0.48 \mathrm{ppqv})$ than the win-
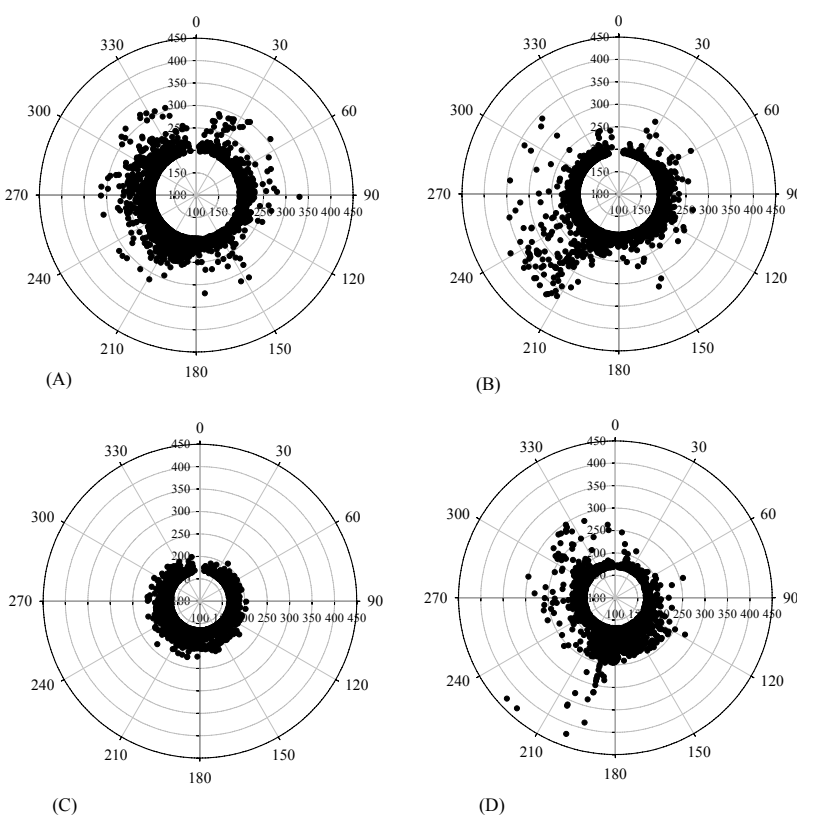

(D)

Fig. 9. Wind roses for high- $\mathrm{Hg}^{0}$ events (above seasonal 85 th percentile value) at Thompson Farm during (a) winter, (b) spring, (c) summer and (d) fall, 2007. Data are 5-min averages.

tertime mean ( 0.4 ppqv). During mixed precipitation events, mean RGM was $0.24 \pm 0.3$ ppqv, intermediate between rain and snow events. These results seem to suggest that RGM is scavenged less efficiently when precipitation is frozen.

Conversely, very weak, positive correlation of $\mathrm{Hg}^{0}$ with RH during the daytime was observed at each site (Table 4). At TF and PM, this may reflect small (typically $\leq 25$ ppqv) enhancements that in $\mathrm{Hg}^{0}$ were observed during some rain events, probably due to enhanced emission from wet soil (e.g., Lindberg et al., 1999; Gustin and Stamenkovic, 2005) or vegetation (e.g., Bash and Miller, 2008). In some cases, $\mathrm{Hg}^{0}$ at both TF and PM were enhanced due to transport from the marine boundary layer during strong storms (Sigler et al., 2009).

\subsection{Wind direction}

$\mathrm{Hg}^{0}$ and RGM mixing ratios showed some dependence on wind direction at each site, which can be best illustrated by examining high- $\mathrm{Hg}^{0}$ and RGM events. Wind roses of $\mathrm{Hg}^{0}$ mixing ratios above the 85 th percentile value for each season at $\mathrm{TF}$ are shown in Fig. 9. These represent $\sim 14 \%$ of all observations at each site during 2007. High $\mathrm{Hg}^{0}$ events were observed under southerly to westerly flow patterns in spring and fall (Fig. 9b, d), while summertime events were both less extreme, with all values $<230$ ppqv (Fig. 9c), and showed no clear directional dependence. This could suggest a more important role of strong localized sinks such as deposition to vegetation at TF in warm seasons (Mao et al., 2008) 


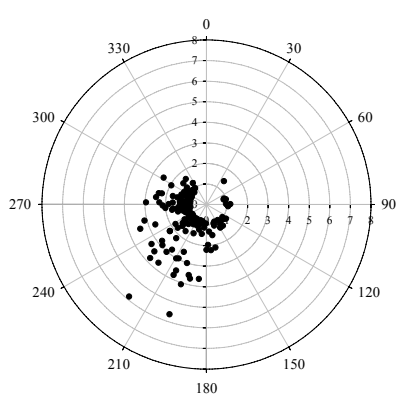

(A)

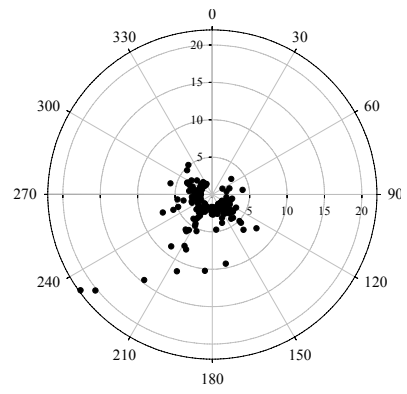

(B)
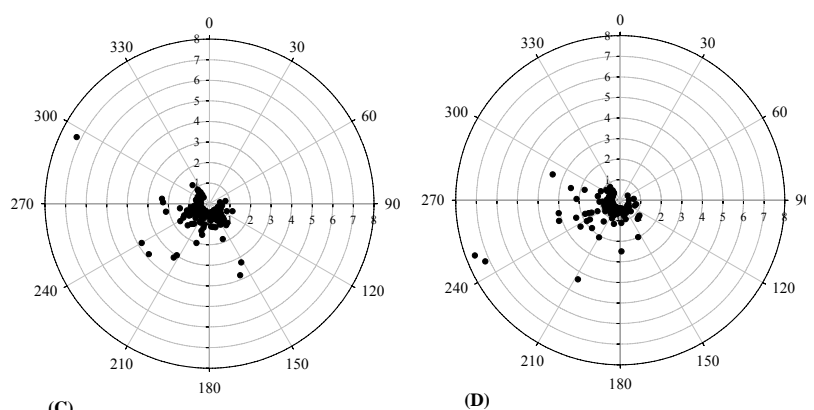

(C)

(D)

Fig. 10. Wind roses for high-RGM events (above seasonal 85th percentile value) at Thompson Farm during (a) winter, (b) spring, (c) summer and (d) fall, 2007.

when high-Hg events are weaker and the directional dependence is diminished, or perhaps weaker local and regional combustion sources. PM exhibited a more pronounced directional dependence for each season although with comparatively fewer high- $\mathrm{Hg}^{0}$ events from the Southwest and West (not shown).

We note that wind roses, which have previously been used in similar RGM studies (e.g., Yatavelli et al., 2006; Manolopoulos et al., 2007b), have limitations for studies involving complex terrain or when more distant sources (e.g., $<50 \mathrm{~km}$ ) may contribute to pollutant levels. In light of this, 48-h back trajectory simulations (NOAA HYSPLIT, Draxler and Rolph, 2003) were performed (not shown) for high RGM events depicted in Fig. 11, and these substantiated the directional bias of the pollution events. Moreover, previous studies by Mao and Talbot (2004a, b) used wind sector analysis for other pollutants $\left(\mathrm{O}_{3}\right.$ and $\left.\mathrm{CO}\right)$ at several AIRMAP sites and found similar results; i.e., that southerly and southwesterly flow transports pollutant-rich air to $\mathrm{NH}$ from Southern New England and that wind direction measurements at TF are well-representative of the region.

High RGM events showed a more pronounced dependence on wind direction at TF and PM (e.g., Fig. 10). At TF, high RGM events were observed more frequently from the Southwest and West during each season. A similar pattern was observed at PM (not shown), although very few events were observed in summer and fall when RGM in general was rarely detected at PM. We hypothesize that these events, which exert a significant influence on the mean RGM levels at each
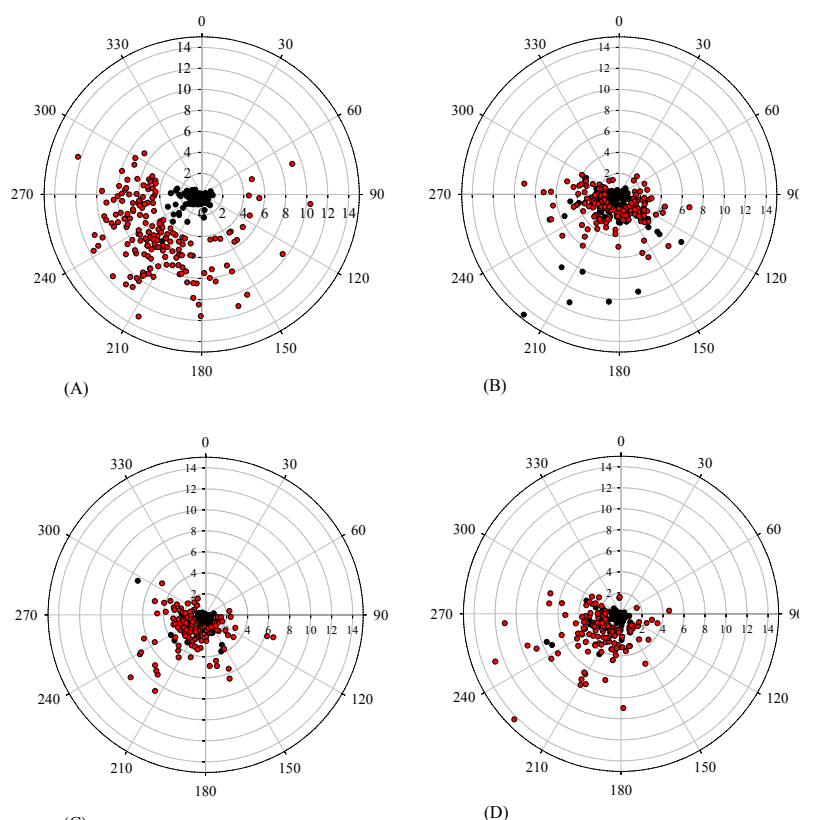

Fig. 11. Wind roses for high-SO $\mathrm{SO}_{2}$ events (above seasonal 85th percentile value) at Thompson Farm during (a) winter, (b) spring, (c) summer and (d) fall, 2007. Angular radius indicates $\mathrm{SO}_{2}$ (red symbols) in ppbv, RGM (black symbols) in ppqv (two-hour averages).

site, are related to transport from combustion sources, which emit significant levels of RGM and $\mathrm{SO}_{2}$ (see Sect. 4). To further illustrate, Fig. 11 depicts wind roses for RGM mixing ratios at $\mathrm{TF}$ during periods in which the $\mathrm{SO}_{2}$ mixing ratio was above the 85th percentile value for each season. These represent $\sim 15 \%$ of all 2-h average $\mathrm{SO}_{2}$ observations. RGM was often significantly elevated during these high $\mathrm{SO}_{2}$ events, ranging on average from two to four times higher than the seasonal mean, and these events occurred most commonly under southwesterly or westerly flow. This strong directional dependence suggests influence from local or regional combustion sources, such as the Merrimack power station in Pembroke, NH ( $\sim 50 \mathrm{~km}$ west of TF), or urban areas south, southwest or west of the site (e.g., Boston, Springfield, MA/Hartford, CT, Albany ( $120 \mathrm{~km}$ west of PM)). The Merrimack power station in particular is the main contributor to the biogenic $\mathrm{Hg}$ "hotspot" in the Merrimack watershed as identified by Evers et al. (2007). In fact, a somewhat stronger tendency for the occurrence of events from easterly sectors was observed at PM compared to TF (not shown) could be explained by anthropogenic sources between PM and TF (e.g., the Merrimack power station, $\sim 50 \mathrm{~km}$ northeast of PM, or sources in Manchester). It is also notable that $\mathrm{Hg}^{0}$ was typically not elevated during these high-SO $2 / \mathrm{RGM}$ events and rarely correlated with $\mathrm{SO}_{2}$ at TF (see Sect. 4), emphasizing the importance of speciated $\mathrm{Hg}$ measurements in tracking local pollution (as in Manolopoulos et al., 2007a).

At AI, high- $\mathrm{Hg}^{0}$ and RGM episodes during summer were most common under southerly or southwesterly flow patterns 
(not shown). These are possibly cases of anthropogenic pollution plumes from Boston and urban Massachusetts influencing AI, as described in Mao and Talbot (2004b).

\section{Summary and conclusions}

A full year of $\mathrm{Hg}^{0}$ and RGM measurements were conducted at two inland sites, TF and PM, from the UNH AIRMAP observing network in New Hampshire throughout 2007, and at a marine site, AI, during summer. We investigated the salient features of $\mathrm{Hg}^{0}$ and RGM mixing ratios at these sites, including seasonal and diurnal variation. Measurements of other trace gases, e.g., $\mathrm{CO}, \mathrm{CO}_{2}, \mathrm{O}_{3}, \mathrm{NO}_{\mathrm{y}}$, and $\mathrm{SO}_{2}$, and meteorological variables were employed in order to better explain this variation as well as natural and anthropogenic controls on the atmospheric Hg budget in New England.

Seasonal variation in both species was observed at TF and PM with higher levels in winter and spring and lower in summer. We attribute this to seasonal variation in deposition strength, meteorological conditions, local anthropogenic sources and biogenic emissions. Our study reinforces the observation of Mao et al. (2008) that the seasonal trend toward decreasing $\mathrm{Hg}^{0}$ during the warmer months at TF is consistent from year to year, owing largely to loss by dry deposition. Our observation of higher RGM during the winter and early spring at TF and lower in the summer is in contrast to many previous studies, and may owe to a combination of local combustion sources for wintertime heating, and increased humidity leading to RGM loss in the summer. This is underscored by the negative relationship observed between RGM and relative humidity at TF and PM.

$\mathrm{Hg}^{0}$ levels were consistent geographically among the three sites during summer of 2007, and throughout the year at PM and TF. This suggests fairly similar regional air mass characteristics from high-elevation areas in Western New Hampshire to the marine boundary layer. However, RGM varies significantly as it is almost absent at PM while detectable in significant quantities at TF and AI. PM is not only distant from major combustion sources and RGM is short-lived in the atmosphere, but high humidity may significantly reduce RGM levels at higher elevations.

Significant correlation of $\mathrm{Hg}^{0}$ and $\mathrm{CO}$ indicates strong contributions from regional anthropogenic emission sources, particularly at PM. The similarity of emission estimates using $\mathrm{Hg}^{0} / \mathrm{CO}$ and $\mathrm{Hg}^{0} / \mathrm{CO}_{2}$ emission ratios suggests that both of these gases may be acceptable tracers for estimating and tracking regional anthropogenic $\mathrm{Hg}$ emissions. At AI, the $\mathrm{Hg}^{0} / \mathrm{CO}$ correlation suggests significant anthropogenic influence in the marine boundary layer in the Gulf of Maine. A positive relationship of RGM with $\mathrm{O}_{3}$ at TF and PM indicates similar photochemical production as well as fast nighttime deposition of these species.

The RGM-SO ${ }_{2}$ relationship at $\mathrm{TF}$, particularly during summer, was driven primarily by a small number of events, suggesting local or regional transport of $\mathrm{RGM}$ and $\mathrm{SO}_{2}$ directly emitted by anthropogenic sources. Enhanced mixing ratios of both species were often observed under southsouthwesterly to westerly flow patterns. Enhanced RGM observed at PM under westerly, southwesterly and easterly flow suggest common influence of combustion sources to the west and southwest of both sites.

The weak, negative relationship of RGM with relative humidity observed at each site may be partly explained by the washout of RGM which frequently occurred during rain events. AT TF in 2007, mean RGM during rain events was below the detection limit of the instrumentation, and is owed to the efficient removal of $\mathrm{Hg}^{2+}$ from the atmosphere by wet precipitation. Future studies of $\mathrm{Hg}$ in wet deposition samples at TF are needed to better understand and quantify this removal process.

Pronounced diurnal patterns in both $\mathrm{Hg}^{0}$ and RGM were observed at TF, particularly in spring, and roughly correlated with air temperature and $j \mathrm{NO}_{2}$, likely reflecting downward mixing from aloft, enhanced soil emissions and photochemical production. Solar angle appears to be an important control on seasonal variation in RGM. During summer at AI, not only was mean RGM significantly higher than at the other two sites, but the diurnal patterns of $\mathrm{Hg}^{0}$ and RGM were strikingly different than at $\mathrm{TF}$ as they were nearly opposite in phase, with $\mathrm{Hg}^{0}$ decreasing through late afternoon, suggesting strong photochemical oxidation of $\mathrm{Hg}^{0}$ to $\mathrm{RGM}$ in the marine boundary layer. The photochemical sink appears to be far more significant than at TF and PM. This is likely due to the presence of halogen radicals derived from marine halogen compounds (e.g., $\mathrm{CHBr}_{3}, \mathrm{CH}_{2} \mathrm{Br}_{2}$ ) which have a short photochemical lifetime and have previously been observed in significant levels at AI (Zhou et al., 2005, 2008).

The presence of halogen compounds at TF, as well as similar $\mathrm{Hg}^{0}$ levels and $\mathrm{Hg}^{0}-\mathrm{CO}$ ratios at $\mathrm{TF}$ and $\mathrm{AI}$ suggests that similar air masses are prevalent at these sites. Ongoing, yearround measurements at $\mathrm{TF}$ and $\mathrm{AI}$ are intended to better understand the interplay of continental and maritime air masses on atmospheric $\mathrm{Hg}$ species at coastal and oceanic sites. In addition, future measurement campaigns are planned with the goal of understanding the particulate component of $\mathrm{Hg}$ in the MBL and the degree to which RGM deposits to sea salt aerosols.

Acknowledgements. Financial support for this study was provided through the Office of Oceanic and Atmospheric Research of the National Oceanic and Atmospheric Administration under AIRMAP grant "NA06OAR4600189 to UNH. We thank K. Carpenter, S. Whitlow, K. Garrison, C. Parker, P. Kelly and others who have contributed to the mercury measurements and management of the extensive AIRMAP database. We also thank two anonymous reviewers for providing criticism toward a stronger manuscript.

Edited by: J. W.Bottenheim 


\section{References}

Aspmo, K., Gauchard, P., Steffen, A., Temme, C., Berg, T., Bahlmann, E., Banic, C., Dommergue, A., Ebinghaus, R., Ferrari, C., Pirrone, N., Sprovieri, F., and Wibetoe, G.: Measurements of atmospheric mercury species during an international study of mercury depletion events at Ny-Ålesund, Svalbard, spring 2003. How reproducible are our present methods?, Atmos. Environ., 39, 7607-7619, 2005.

Bash, J. O. and Miller, D. R.: A relaxed eddy accumulation system for measuring surface fluxes of total gaseous mercury, J. Atmos. Ocean. Tech., 25, 244-257, 2008.

Calvert, J. G. and Lindberg, S. E.: Mechanisms of mercury removal by $\mathrm{O}_{3}$ and $\mathrm{OH}$ in the atmosphere, Atmos. Environ., 39, 33553367, 2005.

Carpi, A.: Mercury from combustion sources: A review of the chemical species emitted and their transport in the atmosphere, Water Air Soil Pollut., 56, 745-767, 1997.

Draxler, R. R. and Rolph, G. D.: HYSPLIT (HYbrid Single-Particle Lagrangian Integrated Trajectory) Model access via: http://www. arl.noaa.gov/ready/hysplit4.html, NOAA Air Resources Laboratory, Silver Spring, MD, USA, 2003.

Engle, M. A., Tate, M. T., Krabbenhoft, D. P., Kolker, A, Olson, M. L., Edgerton, E. S., DeWild, J. F., and McPherson, A. K.: Characterization and cycling of atmospheric mercury along the central US Gulf Coast, Appl. Geochem., 23, 419-437, 2008.

EPA (United States Environmental Protection Agency): Mercury Study Report to Congress, online available at: www.epa.gov/ mercury.html, 1997.

EPA: US Greenhouse Gas Inventory Reports, online available at: http://www.epa.gov/climatechange/emissions/usinventoryreport. html, 2008a.

EPA: National Emissions Inventory, online available at: http:// www.epa.gov/ttn/chief/net/2002inventory.html, 2008b.

Evers, D. C., Han, Y., Driscoll, C. T., Kamman, N. C., Goodale, M. W., Lambert, K. F., Holsen, T. M., Chen, C. Y., Clair, T. A., and Butler, T.: Biological mercury hotspots in the northeastern United States and southeastern Canada, BioScience, 57, 29-43, 2007.

Fischer, E. and Talbot, R.: Regional $\mathrm{NO}_{3}^{-}$events in the northeastern United States related to seasonal climate anomalies, Geophys. Res. Lett., 32, L16804, doi:10.1029/2005GL023490, 2005.

Gabriel, M. C., Williamson, D. G., Brooks, S., and Lindberg, S. E.: Atmospheric speciation of mercury in two contrasting southeastern U.S. airsheds, Atmos. Environ., 39, 4947-4958, 2005.

Gustin, M. S. and Stamenkovic, L.: Effect of watering and soil moisture on mercury emissions from soils, Biogeochemistry, 76, 215-232, 2005.

Han, Y.-J., Holsen, T. M., Lai, S. O., Hopke, P. K., Yi, S. M., Liu, W., Pagano, J., Falanga, L., Milligan, M., and Andolina, C.: Atmospheric gaseous mercury concentrations in New York State: relationships with meteorological data and other pollutants, Atmos. Environ., 38, 6431-6446, 2004.

Kellerhals, Beauchamp, S., Belzer, W., Blanchard, P., Froude, F., Harvey, B., McDonald, K., Pilote, M., Poissant, L., Puckett, K., Schroeder, B., Steffen, A., and Tordon, R.: Temporal and spatial variability of total gaseous mercury in Canada: results from the Canadian Atmospheric Mercury Measurement Network (CAMNet), Atmos. Environ., 37, 1003-1011, 2003.

Kim, K.-H., Lindberg, S. E., and Meyers, T. P.: Micrometeorologi- cal measurements of mercury vapor fluxes over background forest soils in eastern Tennessee, Atmos. Environ., 29, 267-282, 1995.

Kim, K.-H., Ebinghaus, R., Schroeder, W. H., Blanchard, P., Kock, H. H., Steffen, A., Froude, F. A., Kim, M. Y., Hong, S. M., and Kim, J. H.: Atmospheric mercury concentrations from several observatory sites in the Northern Hemisphere, J. Atmos. Chem., 50, 1-24, 2005.

Knipping, E. M., Lakin, M. J., Foster, K. L., Jungwirth, P., Tobias, D. J., Gerber, R. B., Dabdub, D., and Finlayson-Pitts, B. J.: Experiments and simulations of ion-enhanced interfacial chemistry on aqueous $\mathrm{NaCl}$ aerosols, Science, 288, 301-306, 2000.

Landis, M. S., Stevens, R. K., Schaedlich, F., and Prestbo, E. M.: Development and characterization of an annular denuder methodology for the measurement of divalent inorganic reactive gaseous mercury in ambient air, Environ. Sci. Technol., 36(13), 3000-3009, 2002.

Laurier, F. J. G., Mason, R. P., Whalin, L., and Kato, S.: Reactive gaseous mercury formation in the North Pacific Ocean's marine boundary layer: A potential role of halogen chemistry, J. Geophys. Res., 108(D17), 4529, doi:10.1029/2003JD003625, 2003.

Laurier, F. and Mason, R.: Mercury concentration and speciation in the coastal and open ocean boundary layer, J. Geophys. Res., 112, D06302, doi:10.1029/2006JD007320, 2007.

Lindberg, S. E., Meyers, T. P., Taylor, G. E., Turner, R. R., and Schroeder, W. H.: Atmosphere-surface exchange of mercury in a forest: Results of modeling and gradient approaches, J. Geophys. Res., 97, 2519-2528, 1992.

Lindberg, S. E. and Stratton, W. J.: Atmospheric mercury speciation: Concentrations and behavior of reactive gaseous mercury in ambient air, Environ. Sci. Technol., 32, 49-57, 1998.

Lindberg, S. E., Hanson, P. J., Meyers, T. P., and Kim, K.-H.: Air/surface exchange of mercury vapor over forests - The need for a reassessment of continental biogenic emissions, Atmos. Environ., 32(5), 895-908, 1998.

Lindberg, S. E., Zhang, H., Gustin, M., Vette, A., Marsik, F., Owens, J., Casimir, A., Ebinghaus, R., Edwards, G., Fitzgerald, C., Kemp, J., Kock, H. H., London, J., Majewski, M., Poissant, L., Pilote, M., Rasmussen, P., Schaedlich, F., Schneeberger, D., Sommar, J., Turner, R., Wallschläger, D., and Xiao, Z.: Increases in mercury emission from desert soils in response to rainfall and irrigation, J. Geophys. Res., 104(D17), 21879-21888, 1999.

Lindberg, S. E., Brooks, S., Lin, C. J., Scott, K. J., Landis, M. S., Stevens, R. K., Goodsite, M., and Richter, A.: Dynamic oxidation of gaseous mercury in the arctic troposphere during polar sunrise, Environ. Sci. Technol., 36(6), 1245-1256, 2002.

Liu, B., Keeler, G. J., Dvonch, J. T., Barres, J. A., Lynam, M. M., Marsik, F. J., and Morgan, J. T.: Temporal variability of mercury speciation in urban air, Atmos. Environ., 41, 1911-1923, 2007.

Lynam, M. M. and Keeler, G. J.: Automated speciated mercury measurements in Michigan, Environ. Sci. Technol., 39, 92539262, 2005.

Malcolm, E. G., Keeler, G. J., and Landis, M. S.: The effects of the coastal environment on the atmospheric mercury cycle, J. Geophys. Res., 108, 4357, doi:10.1029/2002JD003084, 2003.

Manolopoulos, H., Schauer, J. J., Purcell, M. D., Rudolph, T. M., Olson, M. L., Rodger, B., and Krabbenhoft, D. P.: Local and regional factors affecting atmospheric mercury speciation at a remote location, J. Environ. Eng. Sci., 6, 491-501, 2007a. 
Manolopoulos, H., Snyder, D. C., Schauer, J. J., Hill, J. S., Turner, J. R., Olson, M. L., and Krabbenhoft, D. P.: Sources of speciated atmospheric mercury at a residential neighborhood impacted by industrial sources, Environ. Sci. Technol., 41, 5626-5633, 2007b.

Mao, H. and Talbot, R.: $\mathrm{O}_{3}$ and $\mathrm{CO}$ in New England: Temporal variations and relationships, J. Geophys. Res., 109, D21304, doi:10.1029/2004JD004913, 2004a.

Mao, H. and Talbot, R.: Role of meteorological processes in two New England ozone episodes during summer 2001, J. Geophys. Res., 109, D20305, doi:10.1029/2004JD004850, 2004 b.

Mao, H., Talbot, R. W., Sigler, J. M., Sive, B. C., and Hegarty, J. D.: Seasonal and diurnal variations of $\mathrm{Hg}^{\circ}$ over New England, Atmos. Chem. Phys., 8, 1403-1421, 2008, http://www.atmoschem-phys.net/8/1403/2008/.

Mason, R. P. and Sheu, G.-R.: Role of the ocean in the global mercury cycle, Global Biogeochem. Cy., 16(4), 1093, doi:10.1029/2001GB001440, 2002.

NESCAUM (Northeast States for Coordinated Air Use Management): Inventory of anthropogenic mercury emissions in the northeast, online available at: www.nescaum.org, 2005.

Obrist, D., Conen, F., Vogt, R., Siegwolf, R., and Alewell, C.: Estimation of $\mathrm{Hg}$ exchange between ecosystems and the atmosphere using ${ }^{222} \mathrm{Rn}$ and $\mathrm{Hg}$ concentration changes in the stable nocturnal boundary layer, Atmos. Environ., 40, 856-866, 2006.

Poissant, L. and Casimir, A., Water-air and soil-air exchange rate of total gaseous mercury at background sites, Atmos. Environ., 32, 883-893, 1998.

Poissant, L., Pilote, M., Xu, X., Zhang, H., and Beauvais, C.: Atmospheric mercury speciation and deposition in the Bay of St. Francois wetlands, J. Geophys. Res., 109, D11301, doi:10.1029/2003JD004364, 2004.

Poissant, L., Pilote, M., Xu, X., Beauvais, C., Constant, P., and Zhang, H., A year of continuous measurements of three atmospheric mercury species in southern Quebec, Canada, Atmos. Environ., 39, 1275-1287, 2005.

Pszenny, A. A. P., Keene, W. C., Jacob, D. J., Fan, S., Maben, J. R., Zetwo, M. P., Springer-Young, M., and Galloway, J. N.: Evidence of inorganic chlorine gases other than hydrogen chloride in marine surface air, Geophys. Res. Lett., 20, 699-702, 1993.

Saiz-Lopez, A., Shillito, J. A., Coe, H., and Plane, J. M. C.: Measurements and modelling of $\mathrm{I}_{2}, \mathrm{IO}, \mathrm{OIO}, \mathrm{BrO}$ and $\mathrm{NO}_{3}$ in the mid-latitude marine boundary layer, Atmos. Chem. Phys., 6, 1513-1528, 2006, http://www.atmos-chemphys.net/6/1513/2006/.
Sigler, J. M. and Lee, X.: Recent trends in anthropogenic emission in the northeast United States, J. Geophys. Res., 111, D14316, doi:10.1029/2005JD006814, 2006a.

Sigler, J. M. and Lee, X.: Gaseous mercury in background forest soil in the northeastern United States, J. Geophys. Res., 111, G02007, doi:10.1029/2005JG000106, 2006b.

Sigler, J. M., Mao, H., Sive, B. C., and Talbot, R. W.: Oceanic influence on atmospheric mercury at coastal and inland sites: A springtime nor'easter in New England, Atmos. Chem. Phys. Discuss., in press, 2009.

Talbot, R., Mao, H., and Sive, B.: Diurnal characteristics of surface level $\mathrm{O}_{3}$ and other important trace gases in New England, J. Geophys. Res., 110, D09307, doi:10.1029/2004JD005449, 2005.

Valente, R. J., Shea, C., Humes, K. L., and Tanner, R. L.: Atmospheric mercury in the Great Smoky Mountains compared to regional and global levels, Atmos. Environ., 41, 1861-1873, 2007.

VanArsdale, A., Weiss, J., Keeler, G., Miller, E., Boulet, G., Brulotte, R., and Poissant, L.: Patterns of mercury deposition and concentration in northeastern North America (1996-2002), Ecotoxicology, 14, 37-52, 2005.

Weiss-Penzias, P., Jaffe, D. A., McClintick, A., Prestbo, E. M., and Landis, M. S.: Gaseous elemental mercury in the marine boundary layer: Evidence for rapid removal in anthropogenic pollution, Environ. Sci. Technol., 37, 3755-3763, 2003.

Yatavelli, R. L. N., Fahrni, J. K., Kim, M., Crist, K. C., Vickers, C. D., Winter, S. E., and Connell, D. P.: Mercury, $\mathrm{PM}_{2.5}$ and gaseous co-pollutants in the Ohio River Valley region: Preliminary results from the Athens supersite, Atmos. Environ., 40, 6650-6665, 2006.

Zhou, Y., Varner, R. K., Russo, R. S., Wingenter, O. W., Haase, K. B., Talbot, R., and Sive, B. C.: Coastal water source of short-lived halocarbons in New England, J. Geophys. Res., 110, D21302, doi:10.1029/2004JD005603, 2005.

Zhou, Y., Mao, M., Russo, R. S., Blake, D. R., Wingenter, O. W., Haase, K. B., Ambrose, J., Varner, R. K., Talbot, R., and Sive, B. C.: Bromoform and dibromomethane measurements in the seacoast region of New Hampshire, 2002-2004, J. Geophys. Res., 113, D08305, doi:10.1029/2007JD009103, 2008. 